\title{
Kunskapen i kyrkorummet Hur kyrkopedagogik skapar bredare förståelse av religion för skolelever
}

\author{
Av SöREN DALEvI
}

In recent years, scholars in the field of Religious Education have noted a tendency to theorize and intellectualize in the teaching of this school subject in Sweden and Norway. The consequence of the theorization is that many who belong to a religious tradition do not recognize themselves when their religion is presented in class. This study is based on texts and images that pupils in a Swedish primary school class (ages 11-12) made after visiting a church. The study shows how the German method Kirchenpädagogik (Church pedagogy) can give primary school pupils a broader understanding of and insights into what religion can be. By visiting a holy place, pupils acquire knowledge of other aspects of the religion in question. The article shows that the learning the pupils themselves emphasize after meeting with a religious place primarily is of aesthetic nature.

Keywords: Religious Education - Kirchenpädagogik - Aesthetic learning - Church • Non-confessional

Sören DALEVI , f. 1969, PhD., Universitetslektor i Religionsvetenskap, Karlstads universitet, 65188 Karlstad.Epost: soren.dalevi@kau.se

\section{INLEDNING}

Det är mars 2012, och jag och en kollega är på ett möte i svenska riksdagshuset som integrationsminister Erik Ullenhag bjudit in till. Det är ett möte med representanter för de flesta stora religiösa traditioner som finns i Sverige, samt ett antal skolforskare. Olika kristna företrädare finns här, men också muslimska företrädare, buddistmunkar, hinduer, humanister ... det ska bland annat handla om hur man kan tolka den svenska skollagen från 2010 och den brännande frågan om konfessionalitet i den svenska skolan. Men det är en helt annan fråga som kommer att bli det jag minns från den där dagen, en fråga som inte var på agendan. Det är en muslimsk teolog som först yttrar den i en bisats: han känner inte igen beskrivningen av sin religion $\mathrm{i}$ svenska läroböcker i religionskunskap. Han upplever att beskrivningen av islam i svenska läromedel och i svensk religionskunskapsundervisning snarare skapar fördomar om islam än förståelse, och han refererar till sin egen svenska skolgång. Plötsligt börjar många räcka upp händerna, för att instämma i detta. Buddistmunken känner inte heller igen sig, inte hindun heller, flera av de kristna representanterna från olika samfund nickar instämmande. Ja, många nickar instämmande, utan att uttryckligen yttra sig i plenum. Skolverkets representant ser svettig ut, och stammar något om att han får undersöka detta ytterligare, och återkomma någon annan gång.

Exemplet visar på det som religionsdidaktiker under senare år noterat: religionskunskapsämnets tendens till teoretisering 
och intellektualisering (t.ex. Skeie, 2015). Konsekvensen av detta är att många som själva tillhör en religiös tradition inte känner igen sig när religionen ifråga presenteras i undervisningen. Man upplever ofta att en erfarenhetsnära och känslomässig dimension saknas (Holmqvist Lidh, kommande). Den här studien utgår från texter och bilder som en svensk mellanstadieklassi åldrarna 11-12 år gjort efter att de fått uppleva ett kyrkorum genom den tyska metoden Kyrkopedagogik. Syftet med studien är att se om Kyrkopedagogik kan ge mellanstadieelever en breddad förståelse och insikt om vad religion kan vara, bortsett från det teoretiserande och intellektualiserande. Hur ger studiebesöksmetodik och mötet med en religions heliga rum genom en icke-konfessionell metod en breddad bild av en religion? Kan mötet med ett heligt rum rentav ge möjlighet till en annan sorts kunskap, och hur ser i så fall den kunskapen ut? Det är kring dessa två frågor som denna artikel kretsar.

Artikelns empiri består av texter och bilder från en svensk mellanstadieklass som under ett pass på dryga 90 minuter får möta ett kyrkorum genom den icke-konfessionella metoden Kyrkopedagogik. Vilken kunskap kan tänkas uppstå när man som elev får möta religiösa artefakter i ett religiöst rum? Vad upplever barnen själva att de lärt sig? Artikeln avslutas med att resultatet av empirianalysen bryts med tysk religionsdidaktisk teori kring estetisk bildning. Studiens resultat visar att elever får med sig nya och framförallt andra kunskaper, primärt av estetisk natur, genom att besöka en religions heliga rum. Kunskaper som bidrar till att ge elever en breddad förståelse av religion.

\section{ETT SKOLÄMNE MED TEORETISK SLAGSIDA}

Erfarenheterna från mötet med integrationsminsiter Erik Ullenhag 2012 är inte unika.
Tvärtom finns flera studier som belyser den svenska religionsundervisningens teoretiska och distanserande slagsida. Kjell Härenstam påtalade redan i boken Skolboks-islam (Härenstam, 1993, jfr Otterbeck, 2006) hur svårt det är att göra en annan religion rättvisa. Härenstam visar övertygande att det som kallades islam i religionsläroböckerna snarare sa mer om den aktuella svenska kontexten och kulturklimatet vid tiden för författandet av läroboken, än vad det sa om islam som religion. Senare visade Härenstam att samma fenomen också gällde beskrivningen av tibetansk buddism (Härenstam, 2000). Och hur religion beskrivs i läroböcker och i religionskunskapsundervisningen är viktigt, inte minst eftersom vi idag vet att skolundervisning och media är de kanaler genom vilka elever främst kommer i kontakt med religion (Bromander, 2012: 67). På senare tid har bl.a. Geir Skeie (Skeie, 2015) och Henry Cöster (Cöster, 2012) belyst hur religionsundervisningen inte bara $\mathrm{i}$ Sverige, utan också i Norge, tenderar att vara alltmer (och kanske alltför) orienterad mot teoretiska och intellektuella kunskaper, och att förståelse för den levda religionen ifråga tenderar att hamna i bakgrunden. Framförallt visar Skeie hur denna fokusering på det teoretiska i sig leder till en mycket speciell syn på religion, ja, hur ämnet genom sin utformning rentav uttrycker en egen religionsdefinition (se även Hylén, 2012, Klasson Sundin, 2010 och Dalevi \& Osbeck, 2012; jfr Cöster, 2012). I en kommande intervjustudie visar Carina Holmqvist Lidh (Holmqvist Lidh, kommande) hur svenska gymnasieungdomar med en religiös tillhörighet har svårt att känna igen sig i skolans religionskunskapsundervisning. De upplever att undervisningen förfrämligar deras egen tradition, och de känner följaktligen inte igen sig $\mathrm{i}$ beskrivningen av sin religion. Undervisningen upplevs som ytlig 
och faktainriktad, där stor vikt fästs vid religiösa dogmer och regler, årtal, «gubbar» och begrepp. Den levda religionen hamnar däremot i bakvattnet, och eleverna upplever att det saknas en erfarenhetsnära och känslomässig dimension i undervisningen. Centrala aspekter av religiöst liv tenderar med andra ord att distanseras och osynliggöras. Och det måste anses vara ett problem när de som tillhör en religiös tradition inte känner igen sig $i$ beskrivningen av den. Som Härenstam konstaterar: «På något sätt måste en framställning bygga på respekt för de människor, för vilka traditionen betyder något» (Härenstam, 2000: 118).

Det finns dock skäl för religionskunskapsämnets teoretisering. Dessa skäl går bl.a. att finna i den svenska skolans historia. Det har påtalats att den svenska skolan långt in på 1900-talet närmast var att jämföra med en religionsskola, inte helt olik de nordafrikanska koranskolor som vi ibland hör talas om i media (Hartman, 2000: 214-215). Detta resulterade i en reaktion på 1960-talet, då ett omdebatterat och svårtolkat krav på objektivitet i religionsundervisningen ledde till vad Hartman kallat för «objektivitetskramp». Den svenska skollagen från 2010 slår dessutom fast att skolan «ska vara icke-konfessionell» (Kap $1 \$ 6)$. Detta har skapat en rädsla, inte minst från många rektorers sida, för att över huvud taget närma sig olika religiösa och ideologiska sammanhang. Denna hållning är lätt att förstå. Som Skeie konstaterar är det svårt att tänka sig något annat ämne $\mathrm{i}$ skolan som skulle ha samma komplexitet och som skulle vara mer känsligt för politiska vindar än vad religionskunskapsämnet är (Skeie, 2015: 129-130). Konsekvensen blir att det är tryggare att läsa läroböcker och, möjligen, se på en film i klassrummet än att t.ex. ge sig ut på studiebesök. Kanske kan detta även för- klara den undersökning av svenska religionskunskapslärare som utfördes för några år sedan. Där framkommer det att bara $16 \%$ av lärarna genomför studiebesök, trots att 93\% av samma lärargrupp tycker att studiebesök är viktiga (Osbeck \& Pettersson, 2009: 218). ${ }^{1}$

Denna slagsida mot intellektuella och teoretiska kunskaper leder således till att många som «lever religionen» inte känner igen sig i religionsundervisningen. Detta medför i sin tur ett djupare problem, som inte bara har med «kunskaper» att göra. Religionskunskapsämnet har nämligen i såväl Sverige som Norge ett bredare uppdrag än att enbart ge faktakunskaper om religion. Ämnet har också ett värdeuppdrag, vad man skulle kunna kalla för ett demokratiskt uppdrag, ett uppdrag som består i att skapa förståelse och acceptans för olika sätt att leva och uttrycka bl.a. sin religion. Den svenska läroplanen Lgr 11 slår initialt fast att «utbildningen inom skolväsendet syftar till att elever ska inhämta och utveckla kunskaper och värden [min kursivering].» Denna paragraf gäller samtliga ämnen i den svenska skolan, men religionskunskapsämnets speciella innehåll gör det till ett ämne där «värden» förefaller extra viktigt. Man kan med Skeie konstatera att religionskunskapsämnet också har i uppgift att socialisera in barn och ungdomar i det som är samhällets värderingar och göra dem till goda medborgare (Skeie, 2015: 133). Och om kunskaperna som ges om en religion upplevs som felaktiga av dem som lever traditionen, vilka konsekvenser får det då för de värden som kommuniceras inom ämnet?

Idenhärartikeln studeras Kyrkopedagogik som ett sätt att minska religionsämnets tendens till teoretisering. Därför är det här på sin plats med en kort bakgrund kring metoden och dess ursprung.

1 Det kan naturligtvis även bero på andra faktorer såsom brist på tid, pengar eller platser att besöka (jfr Halvarson-Britton, 2014: 6). 
KYRKOPEDAGOGIK

Kyrkopedagogik är en metod som uppstod i Tyskland under 1970-1980-talet, och som slagit igenom på bred front i Tyskland under de senaste tio åren. Metoden har varit så framgångsrik att litteraturen om den idag anses vara «oöverblickbar» (Dörnemann, 2011: 23). Rötterna till metoden står att finna i Östtyskland under 1970- och 80-talet. I det ateistiska DDR, där $80 \%$ av befolkningen inte tillhörde någon kyrka, besökte många medborgare ändå kyrkor som turister. Kyrkobyggnaden blev på så sätt en möjlighet att föra vidare såväl kulturellt som religiöst innehåll för kyrkorna i DDR (Grünewald, 2010: 115-117, 191). ${ }^{2}$ Det är först när metoden kommer till Västtyskland på 1980-talet som fokus kommer att hamna på skolelever. Dörnemann lyfter särskilt fram Hamburg och Hannover för att metoden ska uppstå i väst (Dörnemann, 2011: 29. För en delvis annan bild, se Grünewald, 2010: 115ff).

Kyrkopedagogik kan beskrivas som en upplevelsebaserad metodik som strävar efter att göra deltagaren till subjekt och inte objekt i sitt möte med kyrkorummet. I sin svenska form vill metoden vara en öppen form av lärande och möjliggöra «för varje deltagare att hålla den distans till rummets budskap som han eller hon själv väljer» (Pfizinger-Drewes, 2012: 17). ${ }^{3}$ Även i Västtyskland var det, som i Sverige, initialt skolklasser som arbetade med metoden, men under senare år har metoden i Tyskland «spillt över» till bl.a. turistgrupper, som önskar se och lära sig om kyrkorum på nya och oväntade sätt (Dörnemann, 2011). Det faktum att metoden startade som en ideell gräsrotsrörelse på många håll samtidigt förde med sig att metoden kom att se mycket olika ut. «Kyrkopedagogik» föreligger därför inte som ett enhetligt koncept i Tyskland, vilket medfört att somliga riktat kritik mot metoden (Grünewald, 2010: 19-23, jfr Dörnemann, 2011: 13).

Kyrkopedagogik är en metodik som är mycket konkret och som genomgående betonar $\ll$ Kopf, Herz und Hand» (d.v.s. HuvudHjärta-Hand), och som utifrån den lokala kontexten arbetar heuristiskt för att visa på de unika aspekterna i det specifika kyrkorummet. Rutinerade kyrkopedagoger anpassar visningen efter gruppen och dess behov, vilket medför att varje visning får sin unika prägel (jfr Pfizinger-Drewes, 2012: 52). Den reformpedagogiska betoningen på «learning by doing» blir tydlig i det Konfucius-citat som nästan alltid används i kyrkopedagogiska introduktionsböcker: «Jag hör och jag glömmer. Jag ser och jag kommer ihåg. Jag gör och jag förstår» (Pfizinger Drewes, 2012: 25). Dialog och delaktighet är andra honnörsord. Kanske skulle man kunna kalla kyrkopedagogik i sin tyska såväl som sin svenska kontext för en användardisciplin, där den kreativa mångfalden är en integrerad del av metoden.

2 Detta till skillnad från Rupp, som menar att metoden uppstår i Västtyskland på 1990-talet. Rupp verkar dock inte känna till metodens historiska bakgrund, och det är inte heller historiken som står i centrum för Rupps bok. Rupp, s 10.

3 Här ser vi hur skillnaden mellan religionskunskapsämnet i Sverige och Tyskland slår igenom. Metoden har en icke-konfessionell utformning i Sverige, men kan i Tyskland vara såväl konfessionell som icke-konfessionell. Den version som vunnit mest framgång i Sverige är inspirerad av metodens upplägg i Hamburg, där icke-konfessionalitet betonas p.g.a. Hamburgs mångkulturella miljö (för en beskrivning av metodens historik och många olika utformningar, se Grünewald, 2010: 115-193, och Dörnemann, 2011: 22-42). För en fördjupad genomgång av metoden i Sverige, se Upplev kyrkorummet: Kyrkopedagogik för alla åldrar, av Thomas Pfizinger-Dreves (2012), som är den enda svenska introduktionsbok som finns om metoden. För en genomgång av Kyrkopedagogik i Tyskland, se t.ex. Rupp (2008) och Neumann \& Rösener (2009). För en vetenskaplig analys av metoden, se Grünewald, 2010, och Dörnemann, 2011. I Dalevi \& Osbeck finns en beskrivning av hur en visning kan gå till från början till slut i ett svenskt, icke-konfessionellt skolsammanhang (Dalevi \& Osbeck, 2012: 97-99). 
MATERIAL

Empirin som utgör underlaget för denna artikel bygger på texter och bilder från én svensk skolklass, årskurs 5. Empiri har dessutom samlats in från två ytterligare skolklasser på två andra orter. De texter och bilder som här analyseras, och de slutsatser som dras, utgör alltså ett representativt urval från en skolklass, men resultatet stöds av empirin från såväl de andra barnen i klassen som de två andra skolklasserna.

Klassen ifråga var indelad i två grupper, och det var slumpen som avgjorde vilken av de två jag skulle följa. Gruppen kom att bestå av 14 barn, en lärare och en assistent. Jag träffade gruppen innan visningen, och var även med i bakgrunden under visningens genomförande och antecknade. Studien var etikprövad, och såväl barn som föräldrar fick ge sitt informerade samtycke. ${ }^{4}$ Inget av barnen avböjde, och 12 av 14 målsmän godkände att deras barn medverkade i studien. Materialet kom således i detta fall att bestå av 12 texter med tillhörande bilder ${ }^{5}$

Visningen, som genomfördes en kall dag i slutet av november, leddes av två kyrkopedagogiska guider (en präst och en församlingsassistent, båda från den lokala församlingen). Det började med att barnen fick gå runt kyrkan och titta på kyrkogården. Sedan gick de in i kyrkan där de gjorde några upplevelseövningar, bl.a. att ligga tyst i varsin kyrkbänk («för att lyssna på tystnaden»). Därefter fick barnen strosa runt två och två i kyrkan och lägga ett kort med ett frågetecken på valfritt objekt som de ville fråga om i kyrkan. Gruppen gick sedan runt i kyrkan, varje grupp fick förklara varför man lagt sitt kort just på denna plats, och guiderna svarade sedan på frågorna.
Barnen lade bl.a. ut sina kort på altaret, vid predikstolen (här fick de som ville gå upp $\mathrm{i}$ predikstolen), vid dopfunten (där man fick känna på vattnet i funten om man ville), men också vid korset och framme vid altarrunden. Efter ca en timme fick vart och ett av barnen pröva på att spela orgel, varpå man satte sig $\mathrm{i}$ kyrkbänkarna, delade ut ett antal rytminstrument, och sjöng/spelade en adventspsalm, «Bereden väg för Herran». Därefter gick man fram till altartavlan, och var och en fick lysa med en ficklampa på den, och tala om vad man såg i bilden men också om man har något att fråga om ( «jag ser en bok», «jag ser en kvinna klädd i blått» etc.). Avslutningsvis fick man rita något som man själv tyckte var viktigt. Efter visningen, som var ca 90 minuter lång, åkte barnen åter till skolan, åt mat, och sedan hade jag dem i 40 minuter. Jag gjorde en kort muntlig presentation om vem jag var och varför jag ville ha deras texter och bilder. Läraren hade berättat för mig att de just börjat skriva miniuppsatser, varför jag valde att använda mig just av ordet «miniuppsats» när jag presenterade vad de skulle göra, att de kunde tänka att de skrev en minuppsats för en kompis som inte var med på visningen för att berätta om den. De fick sedan ett förtryckt papper var, där jag överst valt att skriva några grundfrågor: «Vad minns du mest av visningen? Varför minns du just detta, tror du? Vad tyckte du om visningen? Berätta!».

\section{METOD OCH VALIDITET}

Metodiskt har jag inspirerats av religionsvetenskapliga forskare som analyserat barns texter och bilder religionsvetenskapligt (t.ex. Lied, 2004, och Hartman \& Torstensson-Ed, 2007). Vad gäller barnens bilder kommer

\footnotetext{
4 Karlstads universitets etikprövningsnämnd har gett sitt godkännande till studiens genomförande. För mer info om studiens genomförande och utformning, inklusive etiska aspekter av undersökningen, se Dalevi \& Osbeck, s 45-70, 113-119.

5 I de tre klasser jag följt har jag ett empiriskt material på totalt 36 texter/bilder. De tre klasserna är geografiskt spridda, och från tre olika sociokulturella miljöer: bruksort, landsbygd samt förort.
} 
analysen primärt att utgå från Gunter Kress och Theo van Leuwens «grammar of visual design », som är ett försök att skapa en «grammatik» över bildkommunikation i en västerländsk kontext. Utgångspunkten är att det finns vissa kulturella regler, en viss klassificering och representativitet som används när man kommunicerar i en given kultur (Kress \& Leuwen, 2006: 1-8). Av speciellt intresse för mig är Kress \& Leuwens klassificeringssystem, och då framförallt de taxonomier de använder där bl.a. del och helhet i en bild analyseras och vilka symboliska processer som storlek, placering och specifika detaljer kan säga om vad en bild visuellt kommunicerar eller kan betyda. I detta sammanhang kommer jag även att använda mig av bildteoretikern Karin Aronssons forskning (1997) kring barns bildskapande.

Metodkritiskt kan frågan ställas hur mycket det egentligen är möjligt att läsa ut ur barnens texter och bilder. Skolan är ett maktsammanhang - det kommer senare i artikeln att framgå hur skolgenren slår igenom på olika sätt i barnens texter och bilder - och frågan blir hur nära eleven själv står sina texter och bilder. Detta är relaterat till frågan om den roll barnet tar sig i text och bild. Chatman konstaterar att det i texter och bilder finns flera olika roller en författare kan ta sig (1979: 146-151, jfr Rimmon-Kennan, 2002: 87-90 och Kress \& Leuwen, 2006: 114-115). ${ }^{6}$ Av dessa är det i detta sammanhang fyra roller som är speciellt intressanta. Dels är det relationen mellan å ena sidan $1 /$ «den verklige författaren» (real author), i detta fall barnet, samt $2 / \ll$ den indirekta författaren» (implied author) som i detta fall är den författarroll barnet tar sig i processen. Hur denna roll konstrueras beror till stor del på den tredje rollen i texten, näm- ligen $3 / \ll$ den tänkte läsaren» (implied reader), d.v.s. den läsare som texten och bilden är ämnad för. Vad utmärker den tänkte läsaren? Jo, barnen visste att de skrev för en vuxen, och att det i förlängningen dessutom fanns en «verklig läsare» (real reader) som är Chatmans fjärde roll. Här kommer således en maktrelation in (Eder \& Fingerson, 2002: 181-183). Vi kan för att låna termer från Prince tänka oss att barnets indirekta författarroll blir som en «mask» eller «persona $\gg$ som barnet tar på sig (1987: 42-43). Givet dessa förutsättningar blir frågan: Hur stor grad av ärlighet finner vi, och hur stor grad av självcensur kan vi tänka oss att eleverna lagt på sig själva? Jag återkommer till denna fråga i den avslutande diskussionen.

\section{«JAG KOMMER MEST IHÅG \\ ORIGEN »}

Barnens tolv bilder går motivmässigt att strukturera in i fyra stycken motivkomplex. Det finns tre bilder av kors, tre bilder av orgeln, två bilder av psalmboken, två bilder av en "ängel” samt två bilder på kyrkan sedd ovanifrån/utifrån. Indelningen i motivkomplex är inte helt okomplicerad; man kan argumentera för olika indelningar. De tre bilderna av orgeln samt de två bilderna av psalmboken tänker jag t.ex. här in under samma motivkomplex, båda motiven handlar om sång/musik, men man hade lika gärna kunnat göra dem till två separata motivkomplex. Till syvende och sist talar varje barns bild och text för sig själv, men jag har i genomgången nedan sett till att få med åtminstone ett uttryck för varje motivkomplex.

Det första exemplet är hämtat från motivkomplexet kyrkan, och är en bild på kyrkans interiör sedd ovanifrån: [bild 1]

6 Jag använder mig här medvetet av just Chatman och Rimmon-Kennan, eftersom de arbetar med ett bredare textbegrepp än vad till exempel Genette (1980) gör. 


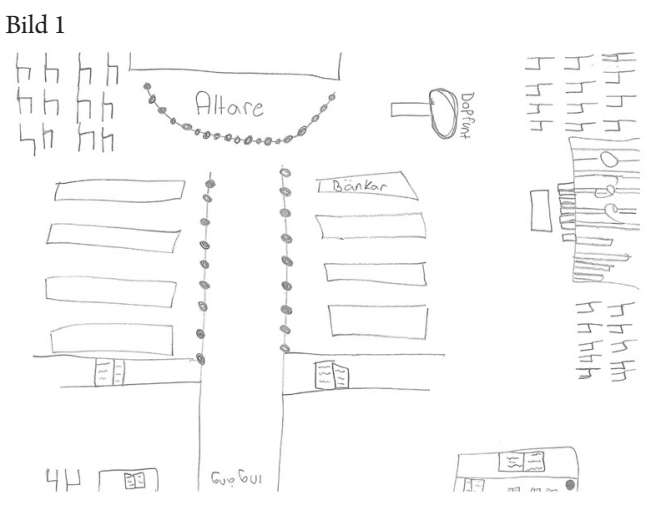

Bilden liknar rent genremässigt ett instuderingsblad eller en läromedelsbild, och kan med Kress \& Leuwens terminologi klassificeras som en «konceptuell representation» (87-88). En konceptuell representation består av ett antal possessiva attribut som, tagna tillsammans, benämner en helhet (i detta specifika fall är de possessiva attributen «altare», «dopfunt», «bänkar», «orgel» samt «ingång», se Kress \& Leuwen, 2006: 50-51). De olika klassificeringarna som skrivs in i bilden - och det är utmärkande för denna genre att de possessiva attributen just skrivs in i bilden - kombineras med att vi får betrakta kyrkorummet från ett distanserat perspektiv («top-down angle»), ett drag som förstärker intrycket av en objektiv faktabild (Kress \& Leuwen, 126). Bilden saknar dessutom färg, ett annat drag som ofta utmärker konceptuella representationer (Kress \& Leuwen, 87-88). Lika intressant som de possessiva attribut som eleven skriver in i bilden är emellertid de detaljer i kyrkorummet som eleven INTE skriver in. Predikstolen och altartavlan, som är två utmärkande artefakter i detta kyrkorum, och som visningen dessutom betonade, lyser t.ex. helt med sin frånvaro. Kress $\&$ Leuwen konstaterar att i valet av possessiva attribut som ska definiera en helhet - i detta fall ett kyrkorum - kommer vissa attribut att skrivas fram, medan andra kommer att hanteras som irrelevanta eller onödiga; som en karta över Australien, där vissa städer skrivs ut medan andra inte gör det (88). Eleven har helt enkelt gjort en värdering. Ett påtagligt faktum i bilden är att orgeln har en oproportionerligt stor dimension jämfört med det verkliga kyrkorummet. Orgeln, som är ca $6 \mathrm{~m}$ lång i verkligheten, är nästan lika lång som kyrkbänkarna, som i det verkliga kyrkorummet upptar ca $20 \mathrm{~m}$. Bildteoretikern Karin Aronsson har påpekat att det i barns bilder ofta är det som de uppfattar som viktigt som framhävs och får stora proportioner. Hon menar att det som ritas större i en bild helt enkelt är viktigare än det som är litet, hon talar om «storleksgraderingar» (Aronsson, 1997: 15, 255-256, jfr Kress \& Leuwen, 2006: 107). Notera att även orgelns pedaler och orgelpallen finns med som detaljer i en bild som annars inte innehåller särskilt mycket detaljer; även dessa är oproportionerligt stora. Att eleven väljer just en konceptuell representation förstärker visningens sammanhang. Konceptuella representationer är extremt vanliga just i skolkontexter, t.ex. som instuderingsblad (där eleven ska fylla i de ord som saknas) eller i läroböcker som instuderingsmaterial. Även den korta text som eleven skrivit förstärker detta; texten avslutas med «Jag tyckte det var ganska roligt att gå runt där, jag fick lära mig mycket».

Baumgärtner har påpekat att en speciell egenskap med bildskapande är att medan en text i en och samma mening kan växla mellan många olika ting, scener och innebörder, så tvingas man i bild att begränsa sig och välja ett motiv och en scen (Baumgärtner, 1968: 65-81). Bilden begränsar således, och det motiv man väljer säger alltså något påtagligt om vad $i$ texten man prioriterar. Bildvalet förstärker och parallelliserar på så sätt någon 
eller några delar av texten, medan andra delar i texten inte förstärks. En annan strategi är att bilden också kan föreställa något som inte alls finns med i texten och som på så sätt «växelverkar» (för att låna Baumgärtners term) med texten. Här fortsätter bilden textens berättande och sätter på så sätt texten i ett nytt och kanske annat ljus. I detta specifika fall ser jag bilden som en logisk fortsättning på elevens avslutande ord: bilden visar att eleven «fick lära sig mycket» och specificerar genom de possessiva attributen just vad det var eleven lärt sig. Bilden fortsätter textens berättande, kompletterar den, och blir m.a.o. en förlängning av texten. Samtidigt får eleven chansen att visa sig duktig och visa på alla de ord den lärt sig, «altare», «dopfunt» etc.

Sammanfattningsvis kan vi konstatera att eleven tydligt anpassat sig till skolkontexten genom att göra en konceptuell representation. Eleven betonar dessutom i texten att den lärt sig mycket, något som sedan visas genom bilden. Vidare lyfts, i såväl text som bild, orgeln fram på ett speciellt sätt.

Orgeln är f.ö. den artefakt som lyfts fram oftast i denna skolklass, och så även i flera av bilderna. Hälften av barnen nämner orgeln $i$ sina texter. «Jag tycker att det var roligaste att spela orgeln $\gg$, «jag kommer mest ihåg origen det var kul» eller «Jag kommer mest ihåg av kyrkan är orlgen som vi fick spela på» är några av barnens skriftliga uttryck för detta. Tre av dem har dessutom valt att enbart rita orgeln på sina bilder. En av dem är en flicka. [bild 2]

Bilden är helt i svart-vitt, med undantag för utsmyckningen i orgelns övre delar, som hon valt att färga guldgult, vilket gör att utsmyckningen framträder tydligare i bilden. Hon har fått med flera av orgelns specifika detaljer, som att den har två «tangentbord» (s.k. manualer, som är placerade terrassfor-
Bild 2

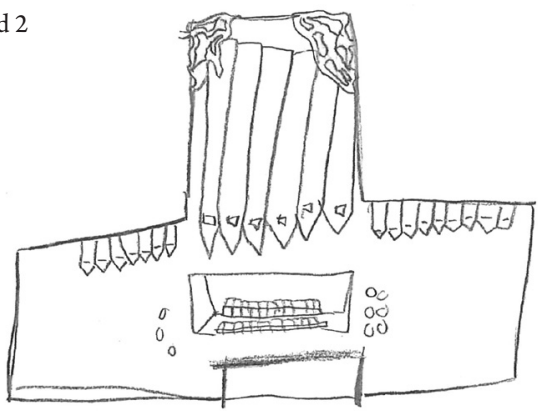

migt ovanför varandra), samt att det finns ett antal runda spakar (s.k. registerandrag) på höger och vänster sida. Hon har även fått med hålen längst ned på orgelpiporna, samt pallen de satt på när de spelade. Man kan notera att hon i sin bild därmed lyfter fram just de detaljer av orgeln som hon själv upplevt: hon har spelat på de två manualerna, hon fick använda registerandragen, hon satt på orgelpallen och hon hörde ljudet från de mäktiga orgelpiporna. Orgelns guldfärgade utsmyckning, som flickan markerat med färg, är också drag som utmärker denna orgel rent visuellt. I sin text skriver flickan: «När vi målade och fick spela orgen var de roligaste men det andra var också roligt. Jag minns det för att det var kul och att vi fick en stund med varandra. Den var jättebra om man har en sån här bra präst så blir det roligt.» Man kan notera att flickan - i likhet med flera av sina kamrater - väljer att svara på papprets inledande tre frågor med en mening per fråga, d.v.s. Vad minns du mest av visningen? - «När vi målade och fick spela orgen var de roligaste men det andra var också roligt.» Varför minns du just detta, tror du? - «Jag minns det för att det var kul och att vi fick en stund med varandra» Vad tyckte du om visningen? Berätta!- «Den var jättebra om man har en sån här bra präst så blir det roligt». Min gissning är att flickan har anpassat sig till skolgenren, och svarat med en mening per fråga som på en instude- 
ringsuppgift. Detta var inte tanken; tanken var att de tre frågorna skulle tjäna som hjälp och inspiration för skrivandet, inte som tre enskilda frågor man skulle besvara var och en för sig. Så blev det dock i flera av fallen i denna klass. Eleverna gick i dessa fall in i elevrollen, på samma sätt som på ett prov eller ett instuderingsblad där man vill svara «rätt» på varje fråga.

Även i detta fall finner vi således en anpassning till skolgenren, och också här framhävs orgeln i såväl text som bild. Vidare verkar det som framhävs i bilden vara just de detaljer som hon själv har använt och upplevt.

Bild 3

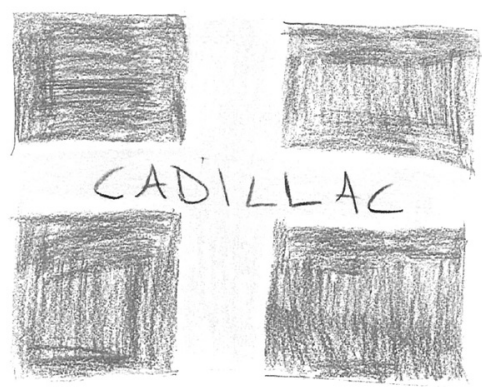

En flicka väljer att rita en svensk flagga med ordet «Cadillac» skrivet rakt över. [bild 3]Denna bild gjorde hon även vid det avslutande teckningsmomentet i kyrkan, där hon dessutom valde att komma fram till mig och visa mig teckningen. I den medföljande texten svarar hon, som flera av de andra eleverna, med en mening per fråga. På första frågan, Vad minns du mest av visningen? «När jag måla en Sverigeflagga som det stod Cadillac på krysset och när vi fick spela orgel». Varför minns du just detta, tror du? «För jag bor i Sverige och att jag har en Cadillac och den betyder mycke för mig». Vad tyckte du om visningen?: «Visningen var okej, för jag tycker inte om att vara i kyrkan och jag tycker inte om att stå still. Annars var det bra». Flaggans gula och blå färg framträder starkt i bilden. Svenska flaggan är, för att tala med Kress \& Leuwen, ett symboliskt attribut, och symboliska attribut görs ofta iögonfallande genom starka färger. Och symboliska bilder har en förmåga att inte bara avbilda ett speciellt moment utan snarare än generaliserad stämning, en essens (Kress \& Leuwen: 105). Korset, eller «krysset» som flickan skriver, är mittcentrerat, till skillnad mot i den svenska flaggan där korset är mer åt vänster. Det gör att korset i flaggan blir ett tydligare kors i flickans bild, men att hon kallar korset för just «kryss» innebär att man lätt blir osäker på om hon förstått att det är ett kors i bilden. Samtidigt skulle korsen i kyrkan (för de har sett några kors under visningen, bl.a. på kyrkogården och över ingången till koret) kunnat inspirera henne till att tänka på flaggan. Vidare skulle Svenska kyrkan eventuellt kunna få henne att associera till det svenska i bred bemärkelse. Dessutom var en svensk flagga hissad i flaggstången utanför kyrkan. Men det faktum att hon skriver «Cadillac» $\mathrm{i}$ bilden, och dessutom skriver att hon äger en Cadillac, ger oss fler ledtrådar. Detta är en del av Sverige där raggarkulturen är relativt stark. Och i raggarkulturen är flaggan viktig; såväl den svenska flaggan som sydstatsflaggan. Och på sydstatsflaggan är det inte ett kors utan just ett «kryss». Är det detta som flickan åsyftar när hon talar om «krysset»?

Flickans association mellan «krysset» och flaggan, och hennes sätt att markera korset i den svenska flaggan, är här intressant. Hon uttrycker dessutom att hon normalt inte tycker om att vara i kyrkan («stå still»). Min tolkning är att hon här ger uttryck för sina olika identiteter, som svensk och del av en raggarkultur, i text och bild.

En annan möjlighet är att flickan uttrycker en sorts protest genom teckningen. Hon skriver trots allt i sin text att hon inte «tycker om 
att vara i kyrkan». I så fall blir «Cadillac » ett sätt att koppla till något som inte alls fanns $\mathrm{i}$ kyrkorummet. Att hon dessutom går fram till mig under visningen och visar bilden är kanske ett sätt att få en reaktion på sin lilla protest?

En annan flicka har ritat en kvinna med gloria, och runt bilden skrivit ett antal possessiva attribut med positiv innebörd: «Fred», «Love», «Fred på jorden», «Kärlek», «Peace» samt "Ängel” (två gånger) [bild 4]. Orden $\ll$ Fred $\gg, ~ «$ Peace $»$ och «Fred på jorden» har liknande för att inte säga samma idéinnehåll, likaså «Kärlek» och «Love» samt de två gånger det står «Ängel». De tre orden till vänster i bilden («Ängel», «Peace» och «kärlek») korrelerar, rentav balanserar, de tre orden till höger i bild («Love», «Ängel», «Fred på jorden»). En viktig fråga blir: vem är flickan? Är det en ängel? För detta talar att orden «ängel» står två gånger runt henne. Eller är det jungfru Maria? Eller flickan själv? För att det är en ängel talar det faktum att den Bild 4

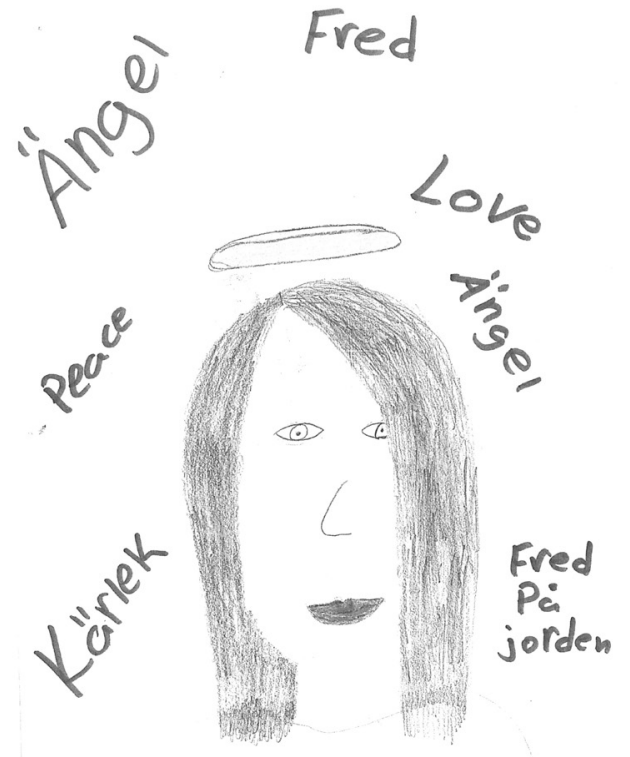

andra flickan som satt vid samma bord ritat av en ängel i helfigur, med änglavingar, och skrivit «Angel» med stora bokstäver högst upp i bilden [bild 5].

Bild 5

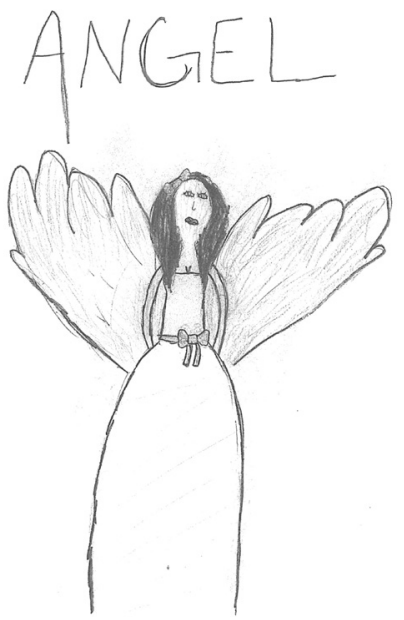

Som Aronsson konstaterar så sker barns bildskapande alltid i ett socialt sammanhang, och dessa gruppgemenskaper spelar stor roll för barnet; det påverkar motiv, färger etc. (Aronsson, 1997: 22). Ängeln har blåa vingar med fem snitt på vardera vinge, och ett lilarosa band runt sin klädnad. Notera hur lika tjejerna på de båda bilderna är, samt att den ena är i helfigur, den andra i halvfigur. I ena fallet har flickan blå vingar med fem snitt på vardera vinge, i andra fallet har flickan en gloria. Vad i visningen inspirerade flickorna att rita detta? Var det bilden av Marie bebådelse, som fanns på altartavlan, och som visar hur Gabriel kommer till den blåklädda Maria? Eller är det förståelsen av kyrkorummet i bred bemärkelse som väckt associationer till änglar? Båda bilder föreställer en flicka som är allvarlig, och som tittar rakt mot betraktaren. Läpparna är markerade i rött, mer tydligt i bild 4 än i bild 5 . I båda fallen har flickan 
en vit klädnad; i bild 5 har flickan ett lilarosa hårband, i bild 4 har hon inget hårband, men håret ligger liknande i båda bilderna. Att bild 4 till stora delar är ritad i blyerts gör att den gula glorian och de röda läpparna framträder extra tydligt. Flickan som gjorde bild fem betonar i sin text att hon speciellt minns när de satte ut frågetecken och spelade musik, eftersom «det var roligast». Hon betonar dessutom att «visningen va rolig och spännande, vi fick veta mycket om kyrkan».

På baksidan till pappret från flickan som gjorde bild 4 finns dessutom en liten blyertsskiss. [bild 6] Den föreställer en flicka (flickan själv?), som sitter i en kyrkbänk med ljushållare på sidorna (sådana ljushållare fanns i den aktuella kyrkan). Flickan har halvlångt hår, är inte helt olik flickan/ängeln/jungfru Maria som hon målat separat [bild 4], och hon sitter i bänken längst fram. Hon ser tillfreds ut, verkar trivas.

Båda bilderna kommunicerar i min tolkning harmoni kombinerat med allvar, med positivt laddade värdeord som «Fred» och «Kärlek». Blyertsskissen förstärker detta intryck. Det är svårt att greppa vad exakt som gör att de båda flickorna ritar just en «ängel», om det är altartavlan med jungfru Marie bebådelse, om det är kyrkorummets miljö och associationsvärld i sig eller om det är en bildgenre flickorna hämtat från ett annat sammanhang.

Bild 6

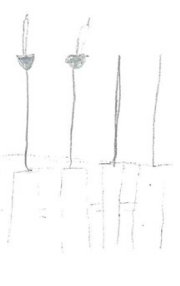

SAMMANFATTANDE

REFLEKTIONER OCH SLUTSATSER

Ett generellt drag i alla exempel som getts $\mathrm{i}$ artikeln, och som också är tydligt i de texter och bilder som av utrymmesskäl inte kunde rymmas, är att det är de estetiska intrycken, av många olika slag, som slår igenom i barnens texter och bilder. Det är rummets estetiska upplevelsevärld i form av orgel, psalmbok, arkitektur, symbolvärld, konst etc. som på ett eller annat sätt lyfts fram. Jag ska ärligt erkänna att resultaten initialt förvånade mig. Jag hade väntat mig att eleverna skulle radda upp fakta, årtal och religiösa symboler (för sådant fanns det rikligt av i visningen). Resultaten visar att religionsämnet kan vara så mycket mer än fakta om gubbar, årtal, symboler, dogmer och trosbekännelser; att religioner också har en stark estetisk dimension i form av musik, bilder, artefakter och arkitektur. Att känna till en religions heliga rum och dess estetiska uttryck kan helt enkelt vara en viktig faktor för att också förstå religion. Kyrkopedagogik kan på så sätt hjälpa till att bredda skolbarns förståelse av religion. En sådan breddad förståelse är, menar jag, dessutom viktig för de «kunskaper och värden» som religionskunskapsämnet har att förmedla.

Dessa resultat är dessutom i linje med teorierna kring «Estetisk bildning», en teoribildning som är på stark frammarsch inom den tyska religionsdidaktiken just nu. En viktig poäng i teoribildningen är att den menar att faktakunskap och begreppslig kunskap måste kompletteras med estetiska kunskaper, med en estetisk kompetens. Teoribildningen adresserar och kritiserar tendensen att kunskap i allt större utsträckning enbart är något som sker i huvudet och att religionskunskapen därmed riskerar att bara bli ett distanserat vetande, utan relevans för elevens egen 
livsvärld (Hilger, 2010, 334). Det handlar dock inte om att ersätta den begreppsliga kunskapen, utan om att komplettera den, grunda den, så att eleven till fullo kan förstå det fenomen som religion är (Dörnemann, 2011: 176, Kalloch, 2010: 228). Bilder, symboler, konst, musik och religiösa rum, och de intryck de gör på eleven, ses som viktiga dimensioner av lärprocessen. I en tid när allt färre elever stöter på religiösa artefakter i sin vardag, är det enligt denna teoribildning viktigt med en «estetisk alfabetisering», för att bättre förstå religionen som fenomen. Det handlar, liksom när man lär sig läsa, om att öva upp en estetisk läsförståelse. Om begreppskunskaper och faktakunskaper blir det enda eleven får med sig, kan det i värsta fall resultera i en estetisk analfabetism, och i förlängningen en mycket partikularistisk syn på religion. Estetiska uttryck såsom religiösa bilder, religiösa symboler och heliga rum möjliggör en annan kunskap, en annan dimension, och ger således en annan förståelse av vad religion också kan vara för den utövande (Kalloch, 2010: 228-229, Hilger, 2010: 334-335).

En viktig poäng inom estetisk bildning är att kunna göra den estetiska händelsen till sin och att kritiskt kunna förstå och analysera den. Det handlar om ett «Lärande med alla sinnen» som inte ersätter det begreppsliga lärandet, men som kompletterar det och gör ämnet mer trovärdigt. Kalloch konstaterar att barn och ungdomar idag allt mer sällan ställs inför sinnliga erfarenheter (utanför datorns värld), vilket leder till en «avestetisering av det mänskliga sinnet med en därpå följande okänslighet [för sinnliga erfarenheter] (Kalloch, 2010: 230). Det handlar om att öva upp en estetisk skicklighet så man blir medveten om sina egna tolkningsmönster. I förlängningen är målet att eleven i mötet med olika typer av artefakter, t.ex. konst, litteratur, film eller musik, ska känna igen religiösa symboler, undertexter och motiv. En viktig poäng är att det här handlar om en bred förståelse av estetikbegreppet, där såväl musik, arkitektur som konst inbegrips. Kalloch konstaterar att estetik ofta förstås snävt, för att ibland enbart handla om religiös konst (Kalloch, 2010: 220-224, jfr Grünewald, 2010: 19-23).

Denna artikels empiri visar att teoribildningen kring estetisk bildning har en poäng: får barn möjligheten att möta estetiska delar av en religion kan en kompletterande och vidgande förståelse och kunskap uppstå. Mellanstadiebarnens möte med ett kyrkorum genom metoden kyrkopedagogik medförde nya och andra kunskaper än vad en förmodad klassrumskontext kan ge. Eleverna får genom sitt möte med ett kyrkorum oväntade kunskaper av estetisk natur i bred bemärkelse. Dessa kunskaper är viktiga för att förstå andra och bredare aspekter av religion, t.ex. en religions kulturella uttryck. Ett tydligt exempel på detta är mötet med orgeln, ett instrument som gjort stort intryck på barnen. Det faktum att de flesta av barnen inte ens kan stava till instrumentet kommer förmodligen av att «orgel» som begrepp är okänt för dem. ${ }^{7}$ Dessutom är det påtagligt $\mathrm{i}$ barnens texter och bilder att de uppskattar mötet med kyrkorummet. Man kan, som jag var inne på tidigare, naturligtvis ifrågasätta hur ärliga barnen hade vågat vara om de hade tyckt illa om besöket, inte minst med tanke på den starka anknytningen till skolgenren som finns i materialet. Samtidigt verkar de uttryck som ges i flera av texterna, t.ex. «det var kul» och «jag lärde mig mycket», vara genuina. En annan reservation är den smala empirin: just denna artikel bygger

7 Notera att det här handlar om ett estetikbegrepp i bred bemärkelse, där såväl orgelns utseende som orgelmusiken räknas som en del av den estetiska upplevelsen, liksom det faktum att eleverna fick röra vid orgeln samt ha en upplevelse av att delta. I en bred estetikdefinition är allt detta en del av ett estetiskt lärande (jfr Kalloch, 2010: 220-224). 
på resultaten från tolv mellanstadiebarn i en skolklass; totalt sett finns empiri från tre skolklasser på tre olika orter. ${ }^{8}$ Empirin från de två andra klasserna visar dock på likartade drag, det är även i dessa de estetiska intrycken som dominerar. Men fler studier skulle behöva göras med fler klasser och på fler orter för att få fatt i andra och kompletterande aspekter kring den kunskap som uppstår i mellanstadiebarns möte med ett kyrkorum.

För att återvända till mars 2012, och mötet med Erik Ullenhag, tänker jag att mötet med en religions heliga rum under skoltiden kan avhjälpa vissa av de luckor som finns i en alltför teoretiserande och intellektualiserande religionsundervisning. I Tyskland har det blivit alltmer vanligt att man besöker kyrkorum även $\mathrm{i}$ andra skolämnen än just religionskunskap. Kyrkorummet är trots allt ett kulturarv i vid bemärkelse: här finns inte bara religion; här finns också historiska, konstvetenskapliga, arkitektoriska och geografiska aspekter av allmänt intresse. Och i Tyskland besöker man inte bara kyrkorum, utan även moskéer och synagogor. Men berättelsen om hur det skulle kunna gestalta sig i Norden, och barnens upplevelser av ett sådant möte det är en annan artikel.

\section{LITTERATUR}

Aronsson, Karin 1997. Barns världar - barns bilder. Natur och Kultur: Stockholm.

Baumgärtner, Alfred Clemens, Erzählung und abbild, s 65-81, i Baumgärtner, Alfred Clemens (red.), 1968. Aspekte der gemalten Welt: 12 kapitel über das Bilderbuch von heute. Verlag Julius Beltz: Weinhem \& Berlin Bromander, Jonas. «Religion som resurs: en översikt av enkätmaterialet», i Lövheim,
Mia \& Bromander, Jonas (red.), 2012. Religion som resurs? Existentiella frågor och värderingar i unga svenskars liv. Artos: Umeå. Chatman, Seymour 1978. Story and Discourse: Narrative Structure in Fiction and Film. Cornell University Press: Ithaca \& London. Cöster, Henry. «Undervisning till likgiltighet», s 251-272, i Osbeck, Christina \& Lied, Sidsel (red.) 2012. Religionsdidaktisk arbeid pågår: Religionsdidaktikk i Hamar og Karlstad. Oplandske Bokforlag: Vallset

Dalevi, Sören \& Osbeck, Christina 2012. Kyrkopedagogik i Munkfors: En utvärdering av ett samarbetsprojekt skola-kyrka. Karlstad University Press: Karlstad.

Dörnemann, Holger 2011. Kirchenpädagogik: Ein religionsdidaktisches Prinzip. Grundannahmen - Methoden - Zielsetzungen. EB Verlag: Berlin.

Eder, Donna, \& Fingersson, Laura, «Interviewing children and adolescents», s 181-201, i Gubrium, Jaber. \& Holstein, James (red.), 2002. Handbook of Interview Research: Context \& Method. Sage: Thousand Oaks.

Genette, Gerard 1980. Narrative discourse: an essay in method. Cornell University Press: New York.

Grünewald, Erica 2010. Kunstgeschichte und Kirchenpädagogik: Ungelöste Spannungen. EB Verlag: Berlin.

Halvarson-Britton, Thérèse 2014. Studiebesök $i$ religionskunskapsundervisningen: Elevers tal om islam före, under och efter ett moskébesök. Karlstad University Studies: Karlstad.

Hartman, Sven, «Hur religionsämnet formades», s. 212-251, i Almén, Edgar, Furenhed, Ragnar, Hartman, Sven G., Skogar, Björn (red.), 2000. Livstolkning och värdegrund: Att undervisa om religion, livsfrågor och etik.

8 I de två andra klasserna har dessutom gruppintervjuer genomförts efteråt. Studien som helhet kommer att publiceras i en bok 2016. 
Skapande Vetande, Linköping.

Hartman, Sven \& Torstensson-Ed, Tullie 2007.

Barns tankar om livet. Natur \& Kultur: Stockholm

Hilger, Georg, «Ästhetisches Lernen», s 334343, i Hilger, Georg, Leimgruber, Stephan

\& Ziebertz, Hans-Georg (red.), 2010. Religionsdidaktik: Ein Leitfaden für Studium, Ausbildung und Beruf. Kösel: München.

Hylén, Torsten, «Essentialism i religionsundervisningen - ett religionsdidaktiskt problem $\gg$ i Nordidactica - Journal of Humanities and Social Science Education, 2012:2, s 106137.

Härenstam, Kjell 1993. Skolboks-islam. Analys av bilden av islam i läroböcker i religionskunskap. Acta Universitatis Gothoburgensis, Göteborg

Härenstam, Kjell 2000. Kan du höra vindhästen? Religionsdidaktik - om konsten att välja kunskap. Studentlitteratur: Lund.

Kalloch, Christina, Leimgruber, Stephan \& Schwab, Ulrich, 2010. Lehrbuch der Religionsdidaktik: Für Studium und Praxis in ökumenischer Perspektive. Herder: Freiburg, Basel \& Wien.

Klasson Sundin, Maria. Barnets rätt - eller föräldrarnas? Tre modeller för barns religionsfrihet, s 39-56 i Ekman, Peter \& Ekh, David 2010. Den blomstertid nu kommer... Fördjupande texter. Sveriges kristna råd: Sundbyberg.

Kress, Gunther \& van Leuwen, Theo 2006. Reading Images: The Grammar of Visual Design. Routledge: London \& New York.

Lied, Sidsel 2004. Elever og livstolkningspluralitet i KRL-faget: Mellomtrinnselever i møte med fortellinger fra ulike religioner og livssyn. Høgskolen i Hedmark: Elverum.

Neumann, Birgit \& Rösener, Antje 2009. Kirchenpädagogik: Kirchen öffnen, entdecken und verstehen: Ein Arbeitsbuch. Gütersloher
Verlagshaus: München.

Osbeck, Christina \& Pettersson, Per, 2009. «Sweden: non-confessional and confessional education. Religious education in public school and in Church of Sweden $\gg, s$ 211-226, i Ziebertz, Hans-Georg \& Ziegel, Ulrich (red) How teachers in Europe Teach Religion: An empirical study in 16 countries. LIT-Verlag: Münster.

Otterbeck, Jonas, «Vad kan man egentligen begära? Läromedelstexter om islam», s 237 262 i Johannessen, Steffen, Andersen, Peter B., Otterbeck, Jonas och Dahlgren, Curt, 2006, Religion, skole og kulturel integration $i$ Danmark og Sverige. Museum Tusculanums Forlag: Köpenhamn.

Pfizinger-Drewes, Thomas 2012. Upplev Kyrkorummet: Kyrkopedagogik för alla åldrar. Argument: Varberg.

Prince, Gerald 1987. Dictionary of Narratology. University of Nebraska Press: Lincoln \& London.

Rimmon-Kenan, Shlomith 2002. Narrative Fiction: Contemporary Poetics. Routledge: London \& New York.

Rupp, Hartmut 2008. Handbuch der Kirchenpädagogik: Kirchenräume wahrnehmen, deuten und erschliessen. Calwer Verlag: Stuttgart.

Skeie, Geir, 2015. «What Does Conceptualisation of Religion Have to Do with Religion in Education?», s. 126-154 i Beaman, Lori G. \& Arragon, Leo van (red.), 2015. Issues in Religion and Education: Whose Religion? Brill: Leiden \& Boston.

\section{Opublicerat material}

Holmqvist Lied, Carina. Representera och bli representerad (manuskript). 